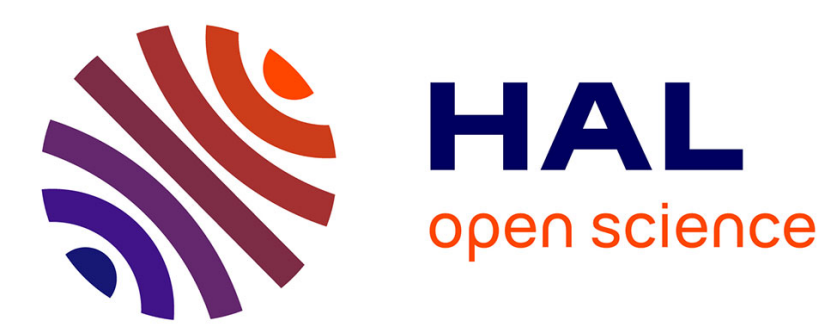

\title{
Book Review: Szasz under Fire: The Psychiatric Abolitionist Faces his Critics
}

\author{
Michael S. Goldstein
}

\section{To cite this version:}

Michael S. Goldstein. Book Review: Szasz under Fire: The Psychiatric Abolitionist Faces his Critics. History of Psychiatry, 2005, 16 (3), pp.375-376. 10.1177/0957154X0501600309 . hal-00570809

\section{HAL Id: hal-00570809 \\ https://hal.science/hal-00570809}

Submitted on 1 Mar 2011

HAL is a multi-disciplinary open access archive for the deposit and dissemination of scientific research documents, whether they are published or not. The documents may come from teaching and research institutions in France or abroad, or from public or private research centers.
L'archive ouverte pluridisciplinaire HAL, est destinée au dépôt et à la diffusion de documents scientifiques de niveau recherche, publiés ou non, émanant des établissements d'enseignement et de recherche français ou étrangers, des laboratoires publics ou privés. 
Jeffrey A. Schaler (ed.). Szasz under Fire: The Psychiatric Abolitionist Faces his Critics. Chicago and La Salle, IL: Open Court, 2004. Pp. xxv + 450. US\$ 36.95. ISBN 0-8126-9568-2.

The 'Under Fire' series allows controversial authors to respond in detail to an array of their critics. The format holds immense potential for both productive exchange, as well as intellectual and academic fireworks. It is difficult to imagine a better way to initiate the series than with the work of Thomas Szasz. Both students and well-established professionals will find much to enjoy and ponder in this useful volume which brings together 12 separate critical essays about specific aspects of Szasz's work, each with a response from Szasz specially written for the volume, as well as a very informative autobiographical sketch and an extensive bibliography of his work. While the editor's introductory essay is adequate, it will be insufficient for a reader not already familiar with Szasz's views.

Szasz is absolutely first rate when it comes to clear writing, logic, passion and the telling example. When Szasz is dissecting the foolishness, unintended consequences, inconsistencies, intellectual pretensions and confusion inherent in topics such as the insanity defence or American drug policy, he is hard to beat. In some cases his job is made easier by the critics (for example, Peele's piece on addiction and Simon's on the insanity defence), who seem not to have read Szasz or made any attempt to deal with what he actually believes. Other essays vary from vague and rambling (Lieberman on 'pharmacracy'), to irrelevant (Hagen on PTSD), to focused and highly appreciative of Szasz despite very different conclusions (Battin and Spellecy on physician-assisted suicide, Bentall on schizophrenia). The acuity of Szasz's responses has a high correlation with the acuity of the attacks. Some, like Slovenko's essay on 'the therapeutic state' and Szasz's response have the feel of a bored old married couple going through the motions of a fight they have had so often that each could do the other's lines to perfection. There is also ample opportunity for a variety of old scores - relating to publications, court testimony and job threats - to be resurrected. The volume ends with a set of letters from 1962 about an attempt to dismiss Szasz from an academic position. Their presence more than 40 years after the event is a reminder of how bitter the animosity between Szasz and some of his adversaries remains.

For most readers the high points of the volume will come in the more general discussions about the nature of disease, and what it really means to call mental illness a 'myth'. Here Szasz is very much on the defensive and, despite his rhetorical skill, it becomes increasingly clear that his time has past. The essay by Kendell effectively demonstrates that Szasz's understanding of illness and disease is simplistic, antiquated and naïve. He shows (pp. 33, 38, 41-2) how Szasz's view of 'real' disease excludes, for example, hypertension, diabetes and many other chronic and acute conditions. To this, Szasz has no real response (p. 51). Szasz's rhetoric relies heavily on 
examples, but examples are not proof, and many of those to which Szasz returns again and again (e.g., the Hinckley case) are in no way representative. Perhaps the best piece in the volume is the one by Engelhardt clarifying Szasz's view that the 'myth of mental illness' is a moral claim, not an empirical or metaphysical statement. Engelhardt manages to be both highly appreciative and critical in assessing Szasz. For once, Szasz's response is one of agreement, with phrases such as 'I am grateful', 'exactly right' (p. 377) and 'faultless representation of my approach to therapy' (p. 387) setting the tone. It is good to see that, while Szasz and so many of his critics are still locked in their decades-old disputes, progress is possible.

MiCHAEL S. GoLDSTEIN University of California, Los Angeles 